\title{
JUDICIAL REVIEW OF DECISIONS OF POLYGAMIC POLICY IN SEMARANG RELIGIOUS COURT
}

\author{
Peni Rinda Listiowati, Achid Ulfi Syukriya \\ Lecturer at Faculty of Law, UNISSULA \\ penirinda00@gmail.com
}

\begin{abstract}
Polygamy is a problem in marriages that is often discussed. Polygamy marriage as regulated in the polygamous marriage law, it is under the principle of monogamy which is not actually the absolute monogamous principle, but it is also called the principle of open monogamy. In the Compilation of Islamic Law (KHI) polygamy is the permission for a husband to have more than one wife on certain conditions. The method used in this legal research was sociological juridical approach that is the juridical review of the judge's verdict on polygamy permit in the Religious Courts of Semarang. The basic consideration to create the benefit of the people is that the active role of the Religious Court judges interpret the law in actual in order to apply the existing law in accordance with the needs of the development of society to achieve the mutual benefit. Elements in the principle of mutual benefit is not only the principle of legal certainty, but in the consideration there must also be the principle of benefit and the principle of justice
\end{abstract}

\section{Keywords: Juridical Review, polygamy permit, Religious Court.}

\section{A. INTRODUCTION}

In the Islamic view which is contained in the Compilation of Islamic Law, the word marriage is a contract or engagement to justify the sexual relationship between men and women in order to realize the happiness of family life covered by the sense of tranquility and affection in a way blessed by Allah SWT. ${ }^{1}$

Married is the sunna of the prophet, although marriage law is determined from its purpose, marriage can also be mandatory of sunna mubah and haram. Therefore, it is the nature for any human being to marry. In a complex of human life, it raises a marriage problem, the problems that happened in a marriage. Marriage is one of the most important aspects of human life. It is the basic demand of every normal human being, without the marriage of one's life will be imperfect and violates his nature, because Allah SWT has created His creature in pairs, in accordance with the hadith of the Prophet Muhammad:

"From 'a'ishah, Rasulullah SAW, said; marriage is my sunnah, whoever does not teach my sunah, then he is not from my people ".

\footnotetext{
1 Mulyadi, 2008, Perkawinan Indonesia, Universitas Diponegoro Publisher, Semarang, page.9.

2 Hadi daeng mapuna,2011, Jurnal Mimbar Hukum
}

The social phenomenon leads to changes in human behavior that occurs in the society life. This is due to the influence of previous human culture, so that marriage has always been a problem that will continue to exist in the life of society. The problem that the researcher concerns on is the marriage polygamy, which means a marriage system which either party owns or marries several of the opposite sex at the same time. ${ }^{3}$

Polygamy is a debatable issue, the practice of polygamy has existed before Islam existed (pre-Islam) and almost all religions acknowledge the existence of polygamy as the researcher has described all elements of society have recognized the existence of polygamous marriages. Marriage is a complex phenomenon, it is regulated in Law No. 1 of 1974 on Article 3 of polygamy marriage adheres to the principle of monogamy ${ }^{4}$. However in other parts, it is said that in a certain condition polygamy is justified as stipulated in the Marriage Act. This Law is actually just an

Dan Peradilan, edisi No.74, PPHIMM, Jakarta. page 187

3 Op.cit page 186

4 Amir Nurudin Dan Azhari Akmal Taringan, 2006, Hukum Perdata Islam Di Indonesia, Kencana, Jakarta, page 161. 
exception, thus, the articles are listed and the reasons that allow it.

In Article 4 of Law No.1 Year 1974 on Marriage states that a husband may take more than one wife if:

1. The wife cannot perform her duty.

2. The wife has body defects and diseases that cannot be cured.

3. The wife cannot bear the children.

With the articles that allow for polygamy, however, for some reason, it is clear that the principle regulated by marriage law is not really an absolute monogamous principle of neglect, nor it is open monogamy. ${ }^{5}$

In addition, in the compilation of Islamic law polygamy is a permission for a husband to have more than one wife under condition. He gets the consent of the first wife, and the certainty of the husband to guarantee the necessities of life of his wife and children as well as to ensure that the husband will be fair to the wives and children as stated in Article 58 compilations of Islamic law.

According to Islamic law, what is meant by marriage is a contract that justifies the association and limits the rights and obligations and mutual help between a man and a woman who between the two is not muhrim to be halal become a family relationship ${ }^{6}$. While the purpose of marriage in Islam is to fulfill the demands of humanity hajad in order to realize a happy family, with the basis of love and affection to obtain a legitimate offspring in society by following the provisions set by the shari'ah. ${ }^{7}$ So what is the procedure and implementation of the permission of polygamy in the Religious Courts of Semarang. And what are the factors of judges' consideration in the Religious Courts of Semarang in granting polygamy permits?

\section{B. Discussion}

\section{Procedure and Implementation of Polygamy Permit Establishment in Religious Courts of Semarang}

The court is a stage, the judicial process is a kind of game scenes that

5 Yahya Harahap, 1997, Hukum Perkawinan Nasional, Zahir Trading, Medan, page.25-26.

6 Sudarsono, 2005, Hukum perkawinan Nasional, PT. Rineka Cipta, Jakarta, page. 1.

7 Accessed from: http://campus-student.blogspot com/2009/08/analisis-hukum-islam-tentang-pembacaan. html on 1 December 2015. have been set up the game procedure. The residents are law enforcers such as judges, lawyers, witnesses, plaintiffs, defendants and attendees who attend the hearing. ${ }^{8}$ In accordance with Article 19 of RI Law No.48 Year 2009 on Judicial Power, the main duties of the judge are:

1. Receiving a case file.

2. Checking the case submitted to him.

3. Disconnecting the case against him. In the request permit polygamy judges also consider 5 important principles that need to be known in the Law no. 1 year 1974 About Marriage, namely:

1. The purpose of marriage is to form a happy and eternal family (Household) based on the Supreme Godhead;

2. A marriage is lawful, if it is done according to the law of respective religion and belief, and besides that every marriage must be recorded according to the applicable legislation.

3. The husband and wife must have matured both body and soul to be able to establish marriage, so that marriage is only permitted if the man has reached the age of 19 (nineteen) years old and the woman has reached the age of 16 (sixteen) years;

4. In this Law adheres to the principle of monogamy, that a man may only marry a woman, but if desired by the concerned, it is permissible for polygamy, because it is the legal basis and the religion of Islam allows a husband to have more than one wife;

5. The husband and wife bear the noble obligation to uphold the household that becomes the basic joint of the society structure, so that the rights and obligations of the wife is equal to the rights and the position of husband in the life of the household and the association of life in society to foster the family.

Law No.1 of 1974 on Marriage and Islamic law both allow polygamy, Satjipto Rahardjo, 1970, Hukum Masyarakat dan Pembangunan, Alumni Bandung, page.104

JUDICIAL REVIEW OF DECISIONS OF POLYGAMIC POLICY IN SEMARANG RELIGIOUS COURT Peni Rinda Listiowati, Achid Ulfi Syukriy 
under conditions that can guarantee the husband's justice to the wife are fulfilled. Islamic law does not forbid the possibility of polygamy, or having more than one wife, as long as the requirements of justice among the wives can be well fulfilled. Islamic law does allow polygamy, but Islamic law does not regulate administrative procedures in the implementation of polygamy, so that polygamy can be carried out in a lawful order of government, it does not harm one party and does not happen arbitrariness against the wife, then Islamic law in Indonesia governs the process of polygamy. In Government Regulation No. 9/1975 on the Implementation of Law No. 1 of 1974 concerning the marriage of Article 40 states that: "If a husband intends to have more than one wife, he shall submit a written application to the court".

As it is known that in general in the execution of judge's ruling handled by the Religious Courts of Semarang more emphasis on the conditions proposed by polygamists must be in accordance with Law No.1 Year 1974 About Marriage, Government Regulation No.9 Year 1975 About the Implementation of Law No.1 Year 1974 About Marriage and based on Presidential Instruction No.1 year 1991, And based on Compilation of Islamic law Article 55-59. ${ }^{9}$

To give a decision on the permission of polygamy, the judge and the clerk see in advance the requirements submitted by the Petitioners in the permission to do polygamy. In the event that the requirements submitted by the Petitioners to conduct polygamy have fulfilled the provisions of Article 5 of Law No.1 Year 1974 concerning Marriage, namely:

1. Approval of the wife.

This Agreement stipulates that the agreement is verbal before the court or in writing, but the court

9 Interview with Mr. Mamnukhin, Panitera Religious Court Semarang, on 5 February 2016 still calls the wife before the court and the judge listens directly to the agreement, with the requirement of the Respondent to directly approve the judge. The Petitioner cannot falsify the agreement from his wife. Although this is distorted from the general court proceedings in the case of the declaration hearing that written or verbal consent spoken in front of the congregation is legal evidence.

2. There is a certainty that the husband can guarantee the necessities of life for his wife and children.

In order to find out that a Petitioner will provide provisions capable of securing the necessities of the lives of his wives and children, a judge will find it difficult to judge objectively. If one has to assess the ability of the Petitioner to ensure the survival of wives and children, their upcoming child. In the case of guaranteeing that the Petitioners can meet the needs of the wives and children can only be estimated, for that judge in addition to examining how the Petitioner's welfare, as well as everyday actions that are not blameworthy. This is also one of the guarantees for the wife and his children that he will not abandon.

3. There is a guarantee that the husband is fair to his wives and children.

Regarding the guarantee of doing justice is very difficult because of the moral issue of the Petitioner. How his conduct and his actions from the Petitioners, only the maximum of the Petitioners make a confession to do justice, this recognition is very doubtful to be able to guarantee fair, more complicated matters of polygamy.

In addition to the above requirements the judge also sees the provisions of Article 4 Paragraph 2 of Law no. 1 Year 1974 a person who marry more than one wife must also meet one of the requirements, there are: 
1. The wife cannot do her duties as a wife.

2. The wife gets a body defect or disease that cannot be cured.

3. The wife cannot bear offspring. 10

After the letter of application of polygamy was accepted by the Religious Courts of Semarang, then the litigants were summoned and on the appointed day of the trial. The Panel of Judges had advised the Petitioner to be monogamous enough with one wife, but the applicant remained on the petition, after that the judge read the petition, which content is retained by the Petitioner to conduct polygamy.

In the face of the trial that on the Petitioner's petition, the Respondent gave oral reply in the hearing essentially justifying the arguments of the Petitioner and stating that the Respondent who ordered and allowed the Petitioner to remarry another woman, because the Respondent was unable to exercise his duties as a wife (due to old condition) and cannot fulfill a longing for a living. ${ }^{11}$

In accordance with Article 41 of Permission Regulation No. 9 of 1945:

1. it is explained that there is or no reason or arguments that the husband can remarry:

- The wife cannot do her duties as a wife.

- The wife gets a body defect or disease that cannot be cured.

- The wife cannot bear offspring.

2. The presence or absence of consent from the wife, whether oral or written, if the consent is in the form of oral, it must be uttered before the court.

3. The presence or absence of a husband's ability to guarantee the life of his wife and children by showing:

- Acertificate of the husband's income,

- A certificate of income tax evidenced in advance of the trial.

- Another acceptable letter by the court.

\footnotetext{
10 Interview with Mr.. Suparno, Poligamer, on 25 February 2016

11 Interview with Mrs. Purwanti, first wife, on 25 December 2016
}

4. There is and there is no guarantee that the husband applies the arguments against his wife and children in the form of statements or promises in the hearing.

In Article 42 of PP No.9 Year 1975, it is explained that the court must summon and hear the wife and examination by the judge at the latest 30 (thirty) days after receipt of the application letter and its attachments.

In Article 43, it is explained in the judiciary if the judge has obtained the argument and sufficient evidence to permit someone to have more one wife, the court shall grant permission to have more than one wife. While the procedure of polygamy according to Islamic law is based on the provisions of Articles 56, 57 and 58 Compilation of Islamic Law as follows:

a. Husbands who have the right to have more than one wife must get permission from the Religious Courts.

b. Submission of the application for license referred to in paragraph (1) shall be conducted according to procedure as set forth in Chapter VIII of Government Regulation Number 9 Year 1975.

c. Marriages with second, third, or fourth wives without the permission of the Religious Courts, have no legal force. 12

Article 57 Compilation of Islamic Law, the Religious Courts only grant permission to a husband who will take more than one wife if:

a. The wife cannot perform a wife's duty.

b. The wife gets a body defect or disease that cannot be cured.

C. The wife cannot give birth. ${ }^{13}$ If the Religious Court has granted a polygamy permit, then it checks under Article 58 of the Compilation of Islamic Law:

\footnotetext{
12 Malthuf Siraj, 2012, Kompilasi Hukum Islam, Pustaka IImu, Yogyakarta, page.11 13 Ibid, page. 12
} 
1. The presence or absence of a reason that allows one's husband to marry again.

2. Whether or not the consent of the wife, whether oral or written consent, if the agreement is an oral consent, the agreement shall be made before the court.

3. The presence or absence of a husband's ability to ensure the survival of wives and children, by showing:

- Certificate of income of husband signed by treasurer of work place.

- Tax income certificate.

- Another letter of acceptance by the Court.

After the letter of approval of polygamy permit issued by the Religious Court, the stipulation of polygamy permit is used as a special administrative requirement as stated in Article 7 Paragraph 2 of Decision of Minister of Religious Affairs no. 447 Year 2004 which is ${ }^{14}$ :

a. A certificate of marriage from the village head or the grievance of the applicant's residence area is called $\mathrm{N}-1$

b. Quotation of birth crtificate or certificate of origin of prospective bride given by official of the geadman or village head level is called N-2

c. The second consent of the bridegroom called N-3

d. Parent certificate from village or village head ordinary village called $\mathrm{N}-4$

e. Parent's written consent for the unmarried 21-year-old called N-5

f. In the event that no permission from the parent or guardian as mentioned in the letter $E$ above, it requires the permission of the court

g. Dispensation from the courts for prospective husbands who are not yet 19 years old and prospective wives who are not yet 16 years old.

${ }^{14}$ https://kuapagedangan.wordpress.com/pelayanan/ tatacara-poligami/ accessed on 5 January 2016 h. If the prospective bridegroom is a member of the TNI (National Army) or Police then required permission from the boss or his parents

i. Permission from the court for prospective husbands who want to have more than one wife

j. Deed of divorce or excerpts of divorce or divorce registration books for those whose detention prior to the coming into effect of Law No. 7 of 1989

k. The death certificate or death certificate made by the village head or the authorized official for the widower or widow to be remarried is called N-6

I. Permission to marry from foreign embassies

In Letter I KMA No 447 of 2004 Article 7 Letter 2: that the husband must obtain permission from the husband of the court if he wishes to take more than one wife following the implementation of the procedure of Polygamy Procedure:

a. Prospective husband come to the Village request a letter of introduction to the Court with ID and Family Card

b. Coming to the Religious Courts by bringing letters from the village, a letter of approval from the first wife, a statement may be fair, income certificate and other documents required by the Religious Courts

c. Assembly of polygamy permit in the Religious Court

d. Come to the village or village by bringing the permission of polygamy and requesting letters for marriage in the form of certificate, model N1, N2, N3, \& N4

e. Wedding Report to Religious Affairs office District (KUA)

f. Ijab Qabul.

2. Judges Consideration Factors of Religious Courts of Semarang in Granting Polygamy Permits

A Muslim husband who wishes to have more than one wife is required 
to apply for a polygamy permit to a religious court or shari'ah court with the conditions stipulated in Articles 4 and 5 of Law No.1 Year 1974. In order to grant a polygamy permit does not contradict the monogamous principle regulated by Law No. 1 Year 1974, the Religious Courts in examining and deciding cases of polygamy permit applicants must be guided by the following matters:

a. Applicants for polygamy permission must be contemporary, ie the wife must be invited as a petitioner

b. The reason for the permission of polygamy is regulated in Article 4 paragraph 2 of Law No.1 Year 1974 which is facultative, means if one of the requirements can be proven, the religious court can give permission for polygamy.

c. The requirement of polygamy permit set forth in Article 5 Paragraph 1 of Law No.1 Year 1974 is cumulative; the maxim of the religious court may permit the application of polygamy what if the requirement can be fulfilled.

d. The joint treasure in the case of a married husband of more than one wife is already stipulated in Article 94 of the Compilation of Islamic Laws, but it implies injustice, since in certain circumstances it prejudges the wife of the married wife first, therefore the article shall be understood as described in details below.

e. The treasure earned by the husband in the marriage bond with the first wife, is the joint treasure of the husband and the first wife, while the property obtained by the husband in the marriage bond of the second wife and during that time the husband still has marital ties with the first wife, then the joint property is the joint property of the husband, the first wife and the second wife. It will the same as marriage with the third wife and fourth wife.

f. The provision of joint property does not apply to its use for the second wife, third wife, fourth wife (such as house, furniture and shrink) as long as the property of second, third and fourth wives does not exceed $1 / 3$ (one third) of the property acquired by second wife, third and fourth

g. If there is a division of joint property for a husband who has more than one wife for death or divorce, the manner of accounting is as follows for the first wife $1 / 2$ of the joint property of the husband obtained during the marriage, plus $1 / 3 \times$ (one-third of the time) the common property the wife obtains first and second wife, plus $1 / 4$ $x$ (one-quarter times) joint treasure acquired property with his third wife, second wife and first wife, plus $1 / 5 x$ (quarter times) joint treasure tied by first, second, third and fourth wife .

h. The treasures of husband and wife to one, two, three, and four are mutual property with the husband, except those obtained by the husband or wife as a gift or inheritance.

i. At the time of the petition for polygamy permission, husband is obliged to apply for the establishment of joint property with their previous wives, or joint property with previous wives, in the case of husband does not apply for joint property appointments combined with permission of polygamy permission, their wives may apply for the determination of reconvention mutual property collection.

j. In the event that the husband does not apply for the establishment of joint property combined with the application of the polygamy permit and the former wife does not file a joint property stipulation recapitulation in the case of the polygamy permit application as required above the application for polygamy permit is deemed unacceptable.

If the petitioner and the applicant are not present at the hearing, the petition is declared void. According to the 
researcher the presence of both parties is very important in the hearing, the two parties are not present in the hearing, the petition is declared void. Further explained in the legislation specified procedure, reasons, requirements that must be fulfilled and fulfilled by a husband who will do polygamous marriage permit.

In giving answer, in essence the requested acknowledge and justify the following arguments as follows:

a. The Respondent justified the reason of the applicant.

The reason is that the applicant will take more than one wife for reasons because the requested party has no passion to provide for the applicant's soul

b. The Respondent does not object to the applicant.

In accordance with the reasons of the applicant, the requested party shall be united on condition of not mixing the mortgage together due to previous marriage ties and wish a fair trial against the wives and to the children of the applicant and the requested party.

The evidence presented to corroborate the reasons of the applicant is:

a. Candidate of the applicant's wife who gave the information that the applicant argued that the prospective applicant's wife knew that she would be the second wife of the applicant, and that she was willing to live in harmony with the petitioner and the applicant, and would not interfere with the claim of the requested petitioner and the applicant all this time.

b. A statement from the applicant's prospective wife who states she agrees that she respects the prospective wife of the petitioner to marry the petitioner because she loves each other and is willing to be a second wife, stating that the applicant's wife is not related to family, blood relation or relationship and there is no legal obstacle to married premises, and that the prospective applicant's wife is a divorced widow and not in the hands of others, and is willing and able to become a marriage in the marriage of the applicant and the applicant's wife.

c. The verbal statement in front of the panel of judges that the requested party is willing to be combined with the condition of not interfering with the joint property lawsuit already in the applicant's marriage and the applicant, and acknowledging will not be able to satisfy the birthright of the applicant and declaring the truth that the applicant has an income of Rp 20.000.000 / month (two tens of millions per month)

d. Statement of the applicant before the panel of judges to be fair to his wives.

e. The existence of letter proof ${ }^{15}$

1. Photo copy of the marriage certificate between the applicant and the respondent.

2. Photo copy of the applicant and the applicant

3. Photo copy divorce certificate.

4. Statement Letter of no objection to be applied on behalf of the respondent.

5. Aletter of willing statement from the future second wife.

6. The statement shall be fair on behalf of the applicant.

7. Photo copy of the land certificate on behalf of the applicant.

8. Photo copy BPKB.

9. Applicant's Bank Account

From that matter the factors of judge consideration in giving permission to Petitioner to do polygamy, consist of two basic factors of consideration that is base of juridical consideration and base of non-juridical consideration. The judge's judgment factors are as follows: ${ }^{16}$

15 Interview with the Judge Mr. Khoirozi, Judge of the Religious Court of Semarang on 7 February 2016

16 Op cit. 
1. Juridical consideration factor that is the factor of judge consideration related to sitting his case by looking at the arguments presented by the applicant of polygamy permit.

At the beginning of the trial, the Petitioner was able to explain that he had performed a marriage with the Respondent according to Islamic Religion on a certain date in a certain place. After marriage, the Petitioner and the Respondent have lived in harmony as husband and wife, they are blessed with 3 children and 1 adopted child after that in this case proves that the alternative condition Article 4 paragraph 2 a Law No.1 Year 1974 cannot be fulfilled by the Respondent. Then the Petitioner was about to remarry (polygamy) with a woman as the second candidate of the Petitioner's wife because the Petitioner's wife was unable to exercise his duties as a wife. And also from the Petitioner is able to meet the needs of the wives and their children.

From that case, the Petitioner is able to be fair to the Petitioners' wives. Also from the Respondent's statement will be willing and do not mind if the Petitioner remarried with the second wife. Afterwards, from the statement of the Candidate of the two Petitioners' wife will not interfere with the property lawsuit that already existed, but remain intact as joint property between the Petitioner and the Respondent. The existence of the statement of the candidate of the $2^{\text {nd }}$ wife of the applicant orally in court is the ability to live in harmony with the applicant and the requested party,

After that, from the parents and the families of the Respondent and the prospective second wife of the Petitioners stated willingly or not objected if the applicant married a second wife. Because of the side of the Petitioner with a second wife candidate there is no prohibition to conduct marriage, either according to Islamic law or the prevailing laws and regulations. As well as from the Respondent with the applicant's wife there is no blood relation or dairy. Since the Petitioner has polygamy, the wife is the widow status. She is divorced and not tied to another man and the marriage guardian of the second wife of the Petitioner is willing to marry the Petitioner with the second wife candidate for love each other despite being second wife and from the Petitioner side able to pay the whole costs incurred by this case.

2. Basic considerations of Non juridical namely: Basic considerations according to the provisions of Islamic law look at the holy book of the Qur'an and other books that called as yellow book. The basic legal considerations used by the Religious Courts judges of Semarang to establish polygamy permits are not limited to the legal provisions set forth in the provisions of the Act. But also by observing the provisions of Islamic law in the can through the provisions of the can from the holy book Al-qur'an, Al-Hadith, ljma and Qiyas.

In the research results in Semarang Religious Court, the researcher can know the problem of factors from the judges consideration of Semarang Religious Court from the implementation of polygamy permit. Here for all parties concerned, the Petitioner, the Respondent, and the second wife of the Petitioners will get a result the law of the implementation of polygamy, if from the applicant's side get permission from the judge for polygamy, then from the Petitioner with the second wife candidate must be married in the Office of Religious Affairs (KUA) and witnessed by the 
guardian of eachApplicant and second wife candidate. If The applicant with the second wife candidate has been officially married, so then the second wife gave birth, then the child from the second wife to the birth certificate of the child is a child of the Petitioner and the second wife of the applicant.

\section{CONCLUSION}

The implementation of the decision on polygamy permit used by the Religious Courts Court of Semarang is based on the Law No.1 of 1974 Article 4 Paragraph 2 (a). The court will grant a polygamy permit for a man who wishes to have more than one wife if the wife cannot do exercise her duties as a wife, and based on Government Regulation No.9 of 1975 on Implementation of Law No.1 Year 1974 and based on Compilation of Islamic Law article 55-59. As well as alternative and cumulative terms of Law No.1 Year 1974, the alternative terms for the wife cannot perform the obligation as a wife, the wife is experiencing disability or disease that cannot be cured (stroke), and there is also a reasoned wife cannot and the cumulative requirement of the written consent of the wife, the certainty that the husband guarantees the lives of his wives and children, the existence of a guarantee that the husband will be fair to his wife and their children.

Consideration factors used by judges in granting polygamy permits under the provisions of Islamic law have been appropriate and not deviate from the rules or norms of the prevailing religion and consider the factors of juridical consideration and factors of non-juridical consideration: juridical considerations associated with sitting his case by looking the arguments presented by the applicant permit polygamy, Basic Non juridical consideration that is the basis of consideration according to the provisions of Islamic law look at the holy book of the Qur'an and other books that is called as yellow book. The basic legal considerations used by the Religious Courts judges of Semarang to establish polygamy permits are not limited to the legal provisions set forth in the provisions of the Act. But also by observing the provisions of Islamic law in the can through the provisions of the can from the holy book Al-qur'an, Al-Hadith, ljma and Qiyas

So, a court or officer authorized to grant a polygamy application permit shall be selective and very cautious in granting permission, in granting a polygamy permit there should be a control of the court or superior authorities to ensure that conditions have been exercised. It is better for the people of both men (family imam), and women (the main pillar of the family) do not be too despicable of a polygamy or some other problem that in fact every human wants a good in him goodness and eliminate themselves from bad things is the main in the community and the state and for candidates for priests and future mothers of the next generation to think and catch up do not elevate the ego or lust because of family. Happiness is what we are looking to get the blessings of Allah the Almighty.

\section{BIBLIOGRAPHY}

Amir Nurudin Dan Azhari Akmal Taringan, 2006, Hukum Perdata Islam Di Indonesia, Kencana, Jakarta.

Hadi daeng mapuna, 2011, Jurnal Mimbar Hukum Dan Peradilan, edisi No.74, PPHIMM, jakarta Joko Subagyo, 2006, Metode Penelitian Dalam Teori dan Praktek, Rineka Cipta, Jakarta.

Malthuf Siraj, 2012, Kompilasi Hukum Islam, Pustaka IImu, Yogyakarta

Mulyadi, 2008, Perkawinan Indonesia, Badan penerbit Universitas Diponegoro, Semarang;

Satjipto Rahardjo, 1970, Hukum Masyarakat dan Pembangunan, Alumni Bandung;

Sudarsono, 2005, Hukum Perkawinan Nasional, PT.Rineka Cipta, Jakarta;

17 Ibid 
Soerjono Soekanto. 1984. Pengantar Penelitian Hukum, Universitas Indonesia Pers, Jakarta. Yahya Harahap. 1997. Hukum Perkawinan Nasional, Zahir Trading, Medan;

Undang-Undang Nomor 1 Tahun 1974 Tentang Perkawinan

Kompilasi Hukum Islam

http://campus-student.blogspot.com/2009/08/analisis-hukum-islam-tentang-pembacaan.html https://kuapagedangan.wordpress.com/pelayanan/tatacara-poligami/ 